\title{
Trichoderma reesei Mycoparasitism against Pythium ultimum is coordinated by G-alpha Protein GNA1 Signaling
}

Valdirene Neves Monteiro ${ }^{3 *}$, Andrei Stecca Steindorff', Fausto Bruno dos Reis Almeida², Fabyano Alvares Cardoso Lopes ${ }^{1}$, Cirano José Ulhoa $^{4}$, Carlos Roberto Félix ${ }^{1}$, and Roberto Nascimento Silva ${ }^{5}$

${ }^{1}$ Departamento de Biologia Celular, Universidade de Brasília, Asa Norte, 70910-900, Brasília, DF-Brazil

${ }^{2}$ Departamento de Biologia Celular e Molecular e Bioagentes Patogênicos, Faculdade de Medicina de Ribeirão Preto, Universidade de São Paulo, Ribeirão Preto, São Paulo, Brazil

${ }^{3}$ Universidade Estadual de Goiás, Unidade Universitária de Ciências Exatas e Tecnológicas da Universidade Estadual de Goiás-UnUCET, BR 153 , Km 98 Campus Henrique Santillo, Anápolis, GO, 75000-000, Brazil

${ }^{4}$ Department of Biochemistry and Molecular Biology, Federal University of Goiás (UFG), Goiânia, GO, 74001-970, Brazil

${ }^{5}$ Department of Biochemistry and Immunology, RibeirãoPreto Medical School, University of São Paulo, 14049-900, RibeirãoPreto, SP, Brazil

\begin{abstract}
Trichoderma reesei (Hypocrea jecorina) is widely explored in industry and its potential for using in agriculture as a biocontrol agent against phytophatogenic fungi has just began to be investigated. We have investigated the involvement of $\mathrm{G}$ proteins during mycoparasitism against plant pathogens. Here we described the role of GNA1, a $\mathrm{G}$-alpha protein that belongs to $\alpha_{i}$ group in Cell Wall Degrading Enzymes (CWDEs) production by $T$. reesei during antagonism against Pythium ultimum. For that, two mutants were used: $\triangle$ gna1 and gna1QL (=constitutively activated version of GNA1). The gna1QL mutant of $T$. reesei, like the parental TU-6, inhibited the growth of $P$. ultimum in plate confrontation assay and grew faster than the parental TU-6 while the $\Delta g n a 1$ did not grow over $P$. ultimum. Scanning electron microscopy showed that the gna1QL mutant promoted more morphological alterations of $P$. ultimum cell wall than the parental TU-6 while the $\Delta g n a 1$ caused no effects. The mutant $\Delta$ gna1 showed less CWDEs activity than gna1QL and TU-6 during in vitro cultivations. The gna1QL mutant showed a better performance in production of CWDEs such as endochitinase, N-Acetyl- $\beta$-D-glucosaminidase (NAGase), lipase and acid phosphatase, after 72 hours of incubation. However, the parental TU-6 showed higher cellulase activity than gna1QL and $\triangle$ gna1. The intracellular content of cAMP in the strains after 72 hours of incubation in the presence of $P$. ultimum cell wall was: gna1QL (79.85 \pm 12$)$, $\Delta$ gna1 (268.65 \pm 8.5$)$ and TU-6 (109.70 \pm 9.2$)$ pmol/mg protein. RT-qPCR results showed a low level of transcripts of mycoparasitism-specific genes in $\triangle$ gna1 strain. We therefore suggest that the production of some CWDEs during mycoparasitism by $T$. reesei against $P$. ultimum can be mediated by GNA1 activity or cAMP levels.
\end{abstract}

Keywords: Degrading enzymes; G-protein; Mycoparasitism; Trichoderma reesei

\section{Introduction}

The potential of the genus Trichoderma as biocontrol agents of plant disease was first recognized by Weindling in the early 1930s [1], which described the mycoparasitic action of T. lignorum (later renamed as T. virens) on Rhizoctonia solani and Sclerotinia sclerotiorum and its beneficial effects in control of plant pathology. Since then, the genus has been extensively investigated as an antagonist of soil-borne plant pathogens as an alternative to the use of chemical fungicides [2]. $T$. reesei (Hypocrea jecorina), in particular, is widely used for industrial applications such as pulp and paper and biomass degradation for cellulosic ethanol [3]. However, T. reesei has been also employed as a biocontrol agent [4-6].

Biological control by Trichoderma is known as a combination of different mechanisms, among which the most important are: competition for nutrients, production of volatile and non-volatile antibiotics, coiling around the host, and production of hydrolytic enzymes [7]. The mechanism that involves the action of hydrolytic enzymes is called mycoparasitism [2] and results in penetration of the cell wall of the host fungus and utilization of its cellular contents [7]. Mycoparasitism studies have generally focused on the production of chitinases, $\beta$-1,3-glucanases, and proteases [8-10], all of which are closely related to the cell wall composition of the pathogen [11]. We previously reported that other enzymes, such as phosphatases and lipases, are involved in mycoparasitism [5]. Furthermore, using proteomic approaches, we recently also identified a role for a-mannosidase and arabinofuranosidase (ABFase) in mycoparasitism [12].

Pythium is a genus of parasitic oomycete and some species are among the most aggressive soilborne pathogens, causing seed rot and seedling damping-off in many crops [13]. P. ultimum is a ubiquitous plant pathogen and one of the most pathogenic of the genus and because that, their genome was sequenced [14]. Mycoparasitism of $P$. ultimum by Trichoderma involves fungus-fungus interaction and hostpathogen cross-talk with participation of $G$ proteins [15-18], protein kinases [19] and signaling molecules such as cyclic AMP [20]. However, the elucidation of the signaling pathways underlying mycoparasitism is still opened [21].

The $\mathrm{G}$ proteins are a family of guanine nucleotide-binding proteins

*Corresponding author: Valdirene Neves Monteiro, Universidade Estadual de Goiás, Unidade Universitária de Ciências Exatas e Tecnológicas da Universidade Estadual de Goiás-UnUCET, BR 153, Km 98 Campus Henrique Santillo, Anápolis, GO, 75000-000, Brazil, Tel: +55-62-3521-1473; E-mail: valdirene.neves@ueg.br

Received October 07, 2014; Accepted December 01, 2014; Published December 08, 2014

Citation: Monteiro VN, Steindorff AS, Almeida FBR, Lopes FAC, Ulhoa CJ, et al (2014) Trichoderma reesei Mycoparasitism against Pythium ultimum is coordinated by G-alpha Protein GNA1 Signaling. J Microb Biochem Technol 7: 001-007. doi:10.4172/1948-5948.1000173

Copyright: @ 2014 Monteiro VN, et al. This is an open-access article distributed under the terms of the Creative Commons Attribution License, which permits unrestricted use, distribution, and reproduction in any medium, provided the original author and source are credited 
that relay signals from cell surface receptors to intracellular effectors. The involvement of signal transduction pathway components such as $\mathrm{G}$ proteins in control of CWDE expression and coiling processes has been suggested $[5,17,18,22]$. The GNA1, G-alpha protein that belongs to $\alpha_{i}$ group of the fungal G-proteins was already cloned from T. reesei and a mutant carrying a constitutively activated version of and GNA1 (gna1QL) and GNA1 deletion ( $\Delta g n a 1)$ is available $[23,24]$.

The aim of this study was to test the role of the G-alpha protein GNA1 in antagonism of $P$. ultimum by $T$. reesei and in the CWDE production induced by $P$. ultimum cell wall as well. Our findings provide possible functions for GNA1 in mycoparasitism-related processes and suggest an overlapping function in the regulation of mycoparasitism-related genes with another G protein (GNA3) previously described.

\section{Materials and Methods}

\section{Microorganisms and culture conditions}

The uridine auxotrophic $T$. reesei TU-6 mutant strain (ATCC MYA-256), strain PFG1 (=TU-6 retransformed with pyr4 gene), strain expressing constitutively activated version of GNA1 (T. reesei gna1QL) and a gnal deletion strain ( $\Delta g n a 1)$ were obtained from the Institute for Chemical Engineering (Vienna University of Technology, Research Area Gene Technology and Applied Biochemistry, Vienna, Austria) [24]. P. ultimum was obtained from Laboratório de Fitopatologia (Universidade de Brasília, Brasília, Brazil). The microorganisms were maintained on MEX medium (3\% malt extract and agar 2\%

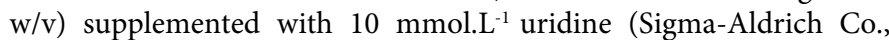
Wisconsin, USA) in case of TU-6.

For production of CWDEs, we have used a mycelium replacement system in $200 \mathrm{~mL}$ of minimal medium as described by [22] supplemented with $0.1 \%(\mathrm{w} / \mathrm{v})$ peptone and $5 \mathrm{~g} / \mathrm{L}$ of previously purified cell wall from P. ultimum as carbon source. The experiments were conducted with three biological replicates. After 24, 48 and 72 hours of incubation the mycelia were harvested by filtration through filter paper and the culture filtrate were used as a source of enzymes. Fungal mycelia were kept at $-80^{\circ} \mathrm{C}$ and used for CAMP analysis and total RNA isolation. The culture filtrate was kept in an ice bath and the filtration was conducted in a cold chamber to avoid cellulase activity.

\section{Biolog Phenotype Microarray analysis}

The global carbon assimilation profiles were evaluated using the Biolog Phenotype MicroArray technique [25], with the Biolog FF Microplate. The T. reesei strains were grown in $2 \%$ malt extract agar under ambient laboratory conditions with diffuse day light at $25^{\circ} \mathrm{C}$. The inocula were prepared after conidial maturation (2-3 days), by rolling a sterile, wetted cotton swab in the area containing the conidia. The conidia were suspended in $16 \mathrm{ml}$ of sterile phytagel $(0.25 \%$ Phytagel,
$0.03 \%$ Tween 40$)$ in disposable borosilicate tubes $(20 \mathrm{~mm} \times 150 \mathrm{~mm})$. The spore solution was mixed manually for 5 seconds and adjusted to a T590 of $75 \% \pm 3 \%$. Next, $100 \mu \mathrm{l}$ of spore solution was transferred to each well of a Biolog FF Microplate. The microplates were kept in the dark at $25^{\circ} \mathrm{C}$. The mycelial growth was assessed by measuring the A750 at $12 \mathrm{~h}$, $24 \mathrm{~h}$, and $48 \mathrm{~h}$. Each Trichoderma strain was analysed in 3 independent experiments, using different inocula. Two-Way ANOVA was used to compare the carbon assimilation between strains. Bonferroni posttests were used to compare replicate mean by each carbon source and compare to parental TU-6. The statistics tests were performed using GraphPad Prism software version 5.00. Only p-values $<0.05$ were considered as significant [26].

\section{Dual culture tests and scanning electron microscopy (SEM) analysis}

Discs of $5 \mathrm{~mm}$ diameter from minimal medium (MM) [(w/v), $\mathrm{MgSO}_{4} .7 \mathrm{H}_{2} \mathrm{O} 0.1 \%, \mathrm{KH}_{2} \mathrm{PO}_{4} 1 \%,\left(\mathrm{NH}_{4}\right) 2 \mathrm{SO}_{4} 0.6 \%$, tri-natriumcitrate. $2 \mathrm{H}_{2} \mathrm{O} 0.3 \%$, glucose $1 \%$, $50 \mathrm{X}$ trace elements solution 1 volume, agaragar 1\%] were taken from the edge of actively growing colonies of fresh fungal cultures and placed on the surface of the MM plate at a spacing of $4 \mathrm{~cm}$. The plates were incubated at $28^{\circ} \mathrm{C}$, and after 4 and 7 days mycelial samples from the interaction region and after contact region were collected and examined by scanning electron microscopy (SEM) [9].

\section{RNA isolation and RT-qPCR}

Total RNA was isolated from the mycelia by grinding with a mortar and pestle under liquid nitrogen, followed by extraction using TRIZOL reagent (Invitrogen, USA) according to the manufacturer's instructions and digested with DNase I (Invitrogen). Total RNA (5 $\mu \mathrm{g})$ from each pooled sample was reverse transcribed into cDNA in the presence of oligo(dT) and ramdom hexamer primer in a volume of 20 $\mu \mathrm{l}$ using the Maxima ${ }^{\mathrm{TM}}$ First Strand cDNA synthesis kit (Fermentas). The synthesized cDNA was diluted with $80 \mu$ of water and used as a template for real-time PCR. Reactions were performed in the iQ5 real-time PCR system (Bio-Rad). Each reaction $(20 \mu \mathrm{l})$ contained 10 $\mu \mathrm{l}$ of MAXIMA SYBR-green PCR Master Mix (Fermentas), forward and reverse primers (500 $\mathrm{nM}$ each, Table 1$)$, cDNA template, and nuclease free water. PCR cycling conditions were $10 \mathrm{~min}$ at $95^{\circ} \mathrm{C}(1$ cycle), $15 \mathrm{~s}$ at $95^{\circ} \mathrm{C}$ followed by $1 \mathrm{~min}$ at $60^{\circ} \mathrm{C}(40$ cycles $)$, and a melting curve of one min at $95^{\circ} \mathrm{C}$ followed by $30 \mathrm{~s}$ at $55^{\circ} \mathrm{C}$ and a final ramp to $95^{\circ} \mathrm{C}$ with continuous data collection (1 cycle) to test for primer dimers and nonspecific amplification. The tefla transcript was used as internal references to normalize the amount of total RNA present in each reaction (Table 1). The expression level of the genes was calculated from the threshold cycle according to the 2- $\Delta \Delta \mathrm{CT}$ method [27]. Determination of the PCR efficiency was performed using triplicate reactions from a dilution series of $\mathrm{cDNA}\left(1,0.1,10^{-2}\right.$ and 10

\begin{tabular}{|c|c|c|c|}
\hline & \multicolumn{3}{|c|}{ Primers for qPCR (5' to 3') } \\
\hline genes & Acession Trire2 & Forward & Reverse \\
\hline cbh1 & 123989 & CCGAGCTTGGTAGTTACTCTG & TCCATGAGGCAATGTTGGCGTTTC \\
\hline gluc83 & 121746 & CAGCAAGCTCAACAACGTCAAGGT & ACGAAGTTGCGGATGTTCTTG \\
\hline lip1 & 106405 & GATTCCTTCGAAGGCTCCTTG & GAGAAGACGGGTGAGTATTGG \\
\hline ap1 & 71566 & TCTTTGCCATCTTGCTGACC & TTGTGCTGAAGATGGACTGC \\
\hline nag1 & 21725 & AATGGAGTGCCGATCATCAC & GACATCGTTCCAGGAATCATCC \\
\hline chit42 & 80833 & GGACATCACTCATGTCATCTACTC & GTCGGTGAAAGCCTCAACGCAC \\
\hline tef1 & 46958 & CCACATTGCCTGCAAGTTCGC & \\
\hline
\end{tabular}

Table 1: List of genes selected for differential expression analysis under mycoparasitic conditions by qPCR. The primers pairs used were designed based on the sequences of $T$. reesei available in the JGI database (http://genome.jgi-psf.org/Trire2/Trire2.home.html). 
$\left.{ }^{3}\right)$. Amplification efficiency was then calculated from the given slopes in the IQ5 Optical system Software v2.0. The experiment was conducted with three repetitions for each sample and results were compared by one-way ANOVA with Dunnett's posttest $(\alpha=5 \%)$ to analyze the differences between conditions related to control sample (TU-6) using GraphPad Prism version 5.00 for Windows.

\section{Enzyme assays}

Cellulase activity was measured as filter paper activity (FPase) as described bydo Nascimento Silva and co-workers. One unit of enzyme activity was defined as the formation of $1 \mu \mathrm{mol}$ of reducing sugars per minute under the conditions of the assay [5]. Endochitinase activity was measured with a colorimetric method using chitin as substrate [8]. One unit of enzyme activity was defined as the amount of enzyme which release $1 \mu \mathrm{mol} \mathrm{N}$-acetylglucosamine in $1 \mathrm{~h}$ at $37^{\circ} \mathrm{C}$. The $\beta-1,3-$ Glucanase activity assay was performed as described previously [28] using laminarin (Sigma) as substrate. The amount of reducing sugar releases from laminarin was determined as described previously [29]. NAGase, Lipase and acid phosphatase activities were determined using the colorimetric method, using the respective p-nitrophenyl-derivated (Sigma-Aldrich Co., Wisconsin, USA) as a substrate. Enzyme activity was assayed by measuring the rate of formation of $\rho$-nitrophenol from substrate. One unit $(\mathrm{U})$ of enzyme activity was defined as the amount of enzyme that releases $1 \mu \mathrm{mol} \rho$-nitrophenol in $1 \mathrm{~min}$ under reaction conditions [26].

The experiments were conducted with three repetitions for each sample and results were compared by one-way ANOVA with Dunnett's post-test $(\alpha=5 \%)$ to analyze the differences between conditions related to control sample (TU-6) using GraphPad Prism version 5.00 for Windows.

\section{Measurement of intracellular cAMP levels}

Intracellular cAMP levels were determined using adirect cAMP enzyme immunoassay kit (Sigma-Aldrich Co., Wisconsin, USA) according to the manufacturer's instructions. cAMP concentration was related to the protein content of the sample. Protein concentration was determined by the method of Bradford using bovine serum albumin as standard (Sigma-Aldrich Co., Wisconsin, USA). The measurements were conducted using the mycelia of $T$. reesei after $72 \mathrm{hs}$ of incubation in presence of $P$. ultimum purified cell wall.

\section{Cell wall purification of $P$. ultimum}

Quantities from 10 to 20 agar plates (PDA) containing mycelium of the $P$. ultimum was inoculated into $1 \mathrm{~L}$ flasks containing $500 \mathrm{ml}$ of liquid medium MYG. These flasks were incubated at a temperature of $28^{\circ} \mathrm{C}$ under constant stirring of $160 \mathrm{rpm}$ in a rotary shaker for 7 days. The mycelium was harvested by filtration through Whatman 01 filter paper and used in the purification wall. The mycelium was ground to powder in liquid nitrogen in a mortar and pestle. After soaking, the mycelia were treated with urea $(8 \mathrm{M} \mathrm{w} / \mathrm{v})$. Then the cell wall extracts were centrifuged for 15 minutes under rotation 10,000 $\mathrm{rpm}$, the supernatant was preparations discarded, and the precipitates rinsed with distilled water. The precipitates obtained after the washings above were homogenized with a solution of ammonium hydroxide $(1 \mathrm{M} \mathrm{v} / \mathrm{v})$, centrifuged for $30 \mathrm{~min}$ at $10,000 \mathrm{rpm}$, and the precipitates rinsed with distilled water as described previously. The last wash the precipitates were resuspended in formic acid $\left(0.5 \mathrm{~mol} \mathrm{~L}^{-1}\right)$ and again centrifuged and washed with distilled water as mentioned above. In the last washing, the $\mathrm{pH}$ was adjusted to $\mathrm{pH} 6.0$ and the precipitates obtained from P. ultimum lyophilized and used as a source inducing.

\section{Results}

\section{Deletion of gna1 leads to a loss in antagonism ability of $T$. reesei against $P$. ultimum}

In order to understand the role of GNA1 in the antagonism of T. reesei against $P$. ultimum, we performed a direct dual culture confrontation tests monitoring the growth of $T$. reesei (TU-6, gna1QL and $\Delta$ gna1) over $P$. ultimum during 7 days. The possible modification on cell wall ultrastructure of $P$. ultimum was evaluated by scanning electron microscopy. Figure 1 shows that both $T$. reesei TU-6 and the gna1QL mutant inhibited the growth of P. ultimum in plate confrontation within 3 days. However, the mutant gna1QL grew faster than the parental TU-6. SEM showed changes in cell wall morphology and growth of $P$. ultimum in the interaction zone with $T$. reesei 72 hours after contact (4 days after inoculation) (Figure 1). TU-6, identified by smaller diameter mycelia, produces holes characteristic of CWDEs production in P. ultimum cell wall though it also showed a wrinkled appearance after 3 days of growth. On the other hand, the mutant gna1QL produced more holes than TU-6, indicating that it displays a higher efficiency of antagonism/CWDEs production. As can be observed in SEM analysis, the mutant $\Delta g n a 1$ did not cause any effect in P. ultimum cell wall (Figure 1), indicating that GNA1 plays an important role on antagonism ability, principally in coiling and CWDEs production.

\section{Deletion of gna1 affects the metabolism and protein secretion in $T$. reesei}

Since $\Delta g n a 1$ strain did not overgrow in dual culture confrontation tests, we performed the global carbon assimilation by Biolog Phenotype MicroArray technique to evaluate the hole of GNA1 in T. reesei metabolism (supplementary material). In general, $\Delta g n a 1$ strain showed a decreasing in carbon assimilation, excepted for glycogen, that showed a statistically significant increase $(\mathrm{P}<0.001)$ when compared with either the parental TU-6 and for the gna1QL. No significant difference $(\mathrm{P}>0.05)$ was found between TU-6 and Agnal in assimilation of L-Phenylalanine, $\beta$-Cyclodextrin, L-Asparagine, Stachyose, Uridine, Maltitol, L-Threonine, L-Serine, L-Sorbose, L-Proline, N-acetyl-DMannosamine, $\alpha$-Methyl-D-Galactoside, among others (supplementary material). The constitutively activation of GNA1, on the other hand, did not affect drastically the metabolism of T. reesei. Interestingly, most of carbon affected assimilation $(\mathrm{P}<0.001)$ were carbohydrates when compared gna1QL and TU-6, as follow: $\alpha$-Cyclodextrin, Dextrin, $\alpha-\mathrm{D}-$ Glucose, D-Mannose, Sucrose, D-Xylose, D-Melezitose, Maltotriose, Turanose, D-Ribose, L-Arabinose, D-Raffinose, and D-Sorbitol. Comparisons of metabolic profile between T. reesei TU-6 and strain PFG1 (=TU-6 retransformed with pyr4 gene) did not show significant difference $(\mathrm{P}>0.05)$ in any carbon source tested (supplementary material). Furthermore, no differences were observed in grow rate on plates between strains (data not shown). Due that, all experiments were conduct with TU-6 as reference and any difference between strains were considered based on carbon assimilation and not on direct growth capacity.

The intracellular level of cAMP in the strains after 72 hours of incubation in presence of $P$. ultimum cell wall was: gna1QL $(79.85 \pm$ 12), sgnal (268.65 \pm 8.5$)$ and TU-6 (109.70 \pm 9.2$) \mathrm{pmol} / \mathrm{mg}$ protein. No significant difference was observed between TU-6 and gna1QL, although $\Delta g n a 1$ showed a high content in cAMP levels. This result is typical for Gai deletion and was already reported by Rocha-Ramírez and Reithner and their co-workers showed that GNA1 is capable to inhibit the adenylate cyclase $[15,17]$. 
The content of extracellular protein in gna1QL was not significantly different with TU-6 $\left(63.5 \mu \mathrm{g}\right.$. $\mathrm{mL}^{-1} \pm 8.23$ and $83.6 \mu \mathrm{g}$. $\mathrm{mL}^{-1} \pm 6.28$ respectively), suggesting that the mutation in GNA1 did not affect the rate of protein production. However, when the gnal gene was deleted, the mutant produced less protein than TU-6 (36.6 $\mu \mathrm{g}$. $\left.\mathrm{mL}^{-1} \pm 6.17\right)$.

\section{GNA1 regulates the expression of CWDEs genes in T. reesei}

In an effort to understand how GNA1 regulates the CWDEs production we performed quantitative PCR (RT-qPCR) to access gene expression profile of T. reesei (strains TU-6, gna1QL, and $\Delta g n a 1$ ) during in vitro mycoparasitism (Figure 2). The results showed that in general, all genes encoding CWDEs analyzed in this study had low transcripts levels when compared with either the TU-6 and for the mutant gna1QL, suggesting a close relationship between GNA1 activity and expression of CWDEs genes. The cbh1 gene was 100-fold more expressed in the mutant gna1QL in comparison to the TU-6 in 48 hours of culture and decreased drastically after 72 hours (Figure 2). Another gene of great importance in mycoparasitism is gluc 83 that encodes to a glucanase [30]. The transcript levelof gluc 83 was the same in TU-6 and mutant gna1QL after 48 hours of cultivation, however, the transcript level of gluc83 in the mutant gna1QL decreased by 1.5 -fold after 72 hours of cultivation (Figure 2). Since P. ultimum has a large amount of $\beta$-1,3-glucans in their cell wall, this result is relevant and indicates that the expression of gluc 83 was being regulated directly or indirectly by GNA1 and not by cAMP, whereas in 72 hs intracellular cAMP levels in the mutants are opposite. The expression of other genes such as nag1, Lip1, chti42 and ap1, which encode respectively for Nagase, lipase, chitinase and acid phosphatase, were also evaluated. The transcript level of four genes showed similar after 72 hours of cultivation in the mutant gna1QL compared to TU-6 (Figure 2). Interestingly, the transcript levelof Lip1, in the mutant gna1QL, showed approximately 10-fold higher within the first 24 hours, compared to the TU-6 (Figure 2). This finding is important because it shows a possible mechanism for transient regulation by GNA1 in the initial degradation of $P$. ultimum cell wall.

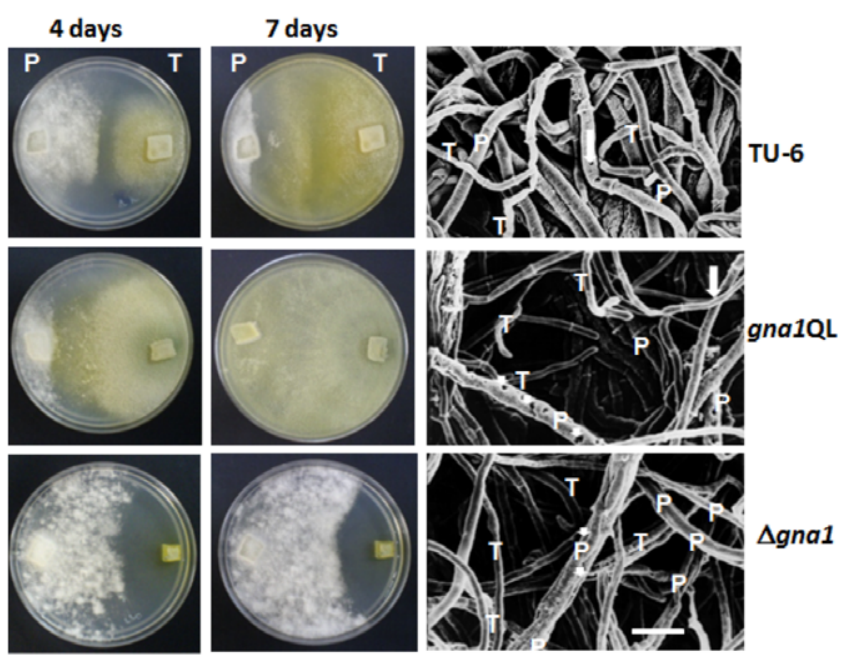

Figure 1: Photographs of dual culture tests and scanning electron microscopy between $T$. reesei (TU-6), $T$. reesei (gna1QL) and $T$. reesei $(\Delta g n a 1)$ and $P$. ultimum. $\mathrm{T}=$ Trichoderma; $\mathrm{P}=P$. ultimum; $\mathrm{Bar}=10 \mu \mathrm{m}$. Arrows show the contact between $T$ and $P$. Arrowheads indicate the holes caused by interaction between $T$ and P. SEM analysis was carried out at $1,800 \mathrm{X}$.

\section{The mutant gna1QL exhibited a high activity of CWDEs during "in vitro" mycoparasitism}

Regarding to mycoparasitism, only the fact that $T$. reesei shows a high or low CWDEs gene expression is not guarantee to biocontrol being successful or unsuccessful. For this reason, we assayed the follow CWDEs activity: cellulase (FPase), glucanase ( $\beta-1,3)$, NAGase, lipase, chitinase, and acid phosphatase. Figure 3 shows that TU-6 showed a high cellulase activity $\left(10.3 \mathrm{U} . \mathrm{mL}^{-1}\right)$ followed by gna1QL (6.46 U. $\mathrm{mL}^{-1}$ ) and $\Delta$ gna1 did not show cellulase activity ( $\mathrm{p} \leq 0.001$ ). The mutant gna1QL exhibited a high endochitinase $(\mathrm{p} \leq 0.01)$ and NAGase $(\mathrm{p} \leq 0.001)$ activities in comparison with TU-6, showing approximately 2 -fold more activity for both enzymes (Figure 3 ) while $\Delta g n a 1$ mutant showed a low endochitinase activity. Reithner and coworkers reported a less chitinase activities and reduced nag1 and ech42 gene transcription in $\Delta$ tgal mutant of $T$. atroviride, thus supporting our results [17]. Furthermore, figure 3 shows that the gna1QL mutant produces $\beta$-1,3-glucanase at a higher level than the parental TU-6 ( $p$ $\leq 0.001$ ) after 48 hours. However, no difference was observed after 72 hours (2.3 U.mL $\mathrm{mL}^{-1}$ and $1.8 \mathrm{U} \cdot \mathrm{mL}^{-1}$ for gna1QL and TU-6 respectively). $\Delta$ gna1 mutant showed low activity of $\beta$-1,3-glucanase $\left(0.74 \mathrm{U}_{\mathrm{mL}}{ }^{-1}\right)$. Since the presence of lipids and phosphate in cell wall have been described for a number of fungi [31], the activities of lipase and acid phosphatase were also investigated. Figure 3 shows that lipase activity in gna1QL (2.23 U.mL $\left.\mathrm{mL}^{-1}\right)$ was higher than in TU-6 (1.37 U.mL $\left.{ }^{-1}\right)(\mathrm{p} \leq 0.001)$ whereas $\Delta$ gnal mutant showed much less activity $\left(0.52 \mathrm{U} \cdot \mathrm{mL}^{-1}\right)$. The role of lipids in fungal cell walls has not been elucidated. However, we can infer from our study that although the mutant gna1QL has a high gene expression of Lip 1 in the first 24 hours, the highest enzyme activity was reached only after 72 hours. The data suggest a long process of post-translational modifications and secretion of lipase and it can be influenced by GNA1.The activity of acid phosphatase is shown in Figure 3. The gna $1 \mathrm{QL}$ mutant showed a high acid phosphatase activity (11.25 U.mL $\left.{ }^{-1}\right)$ when compared with TU-6 (4.88 U.mL $\left.{ }^{-1}\right)(\mathrm{p} \leq 0.001)$ and with $\Delta$ gnal mutant $\left(1.24\right.$ U.mL $\left.{ }^{-1}\right)$. Phosphate has been identified in almost all fungal cell walls analyzed. It ranges from 0.1 to $2 \%$ of the cell wall's dry weight [31]. Here we described that the formation of this enzyme can be regulated by GNA1.

Taken together our results demonstrated that GNA1 protein could regulate the formation of CWDEs directly or indirectly. Furthermore, no direct correlation between gene expression and enzyme activity was observed, taking into account the time points analyzed.

\section{Discussion}

The study of $T$. reesei, a typically industrial fungus, as a biocontrol against $P$. ultimum has just started [4-6] when compared with $T$. harzianum or T. atroviride. Although there is a consensus in the mode of action of Trichoderma during the mycoparasitic process, the molecular and biochemical basis of this process is still unclear and some aspects like CWDEs gene expression and secondary metabolites production must be studied in more detail $[6,13]$. Many reports suggest the participation of signal cascade components such as $G$ proteins, cAMP and MAP kinase in control of mycoparasitism [19]. We have therefore tested the involvement of the G-alpha protein GNA1 of T. reesei in antagonism against $P$. ultimum and in CWDE production during mycoparasitism as well. The gna $1 \mathrm{QL}$ mutant has a single amino acid modification $(\mathrm{Q} 204 \mathrm{~L})$ in the GNA1 protein, which impairs the intrinsic GTPase activity and leads to constitutive activation of this protein [32]. A gna1 deletion strain was obtained by replacement of the coding region with the $H$. jecorina pyr4-gene conferring uridine 

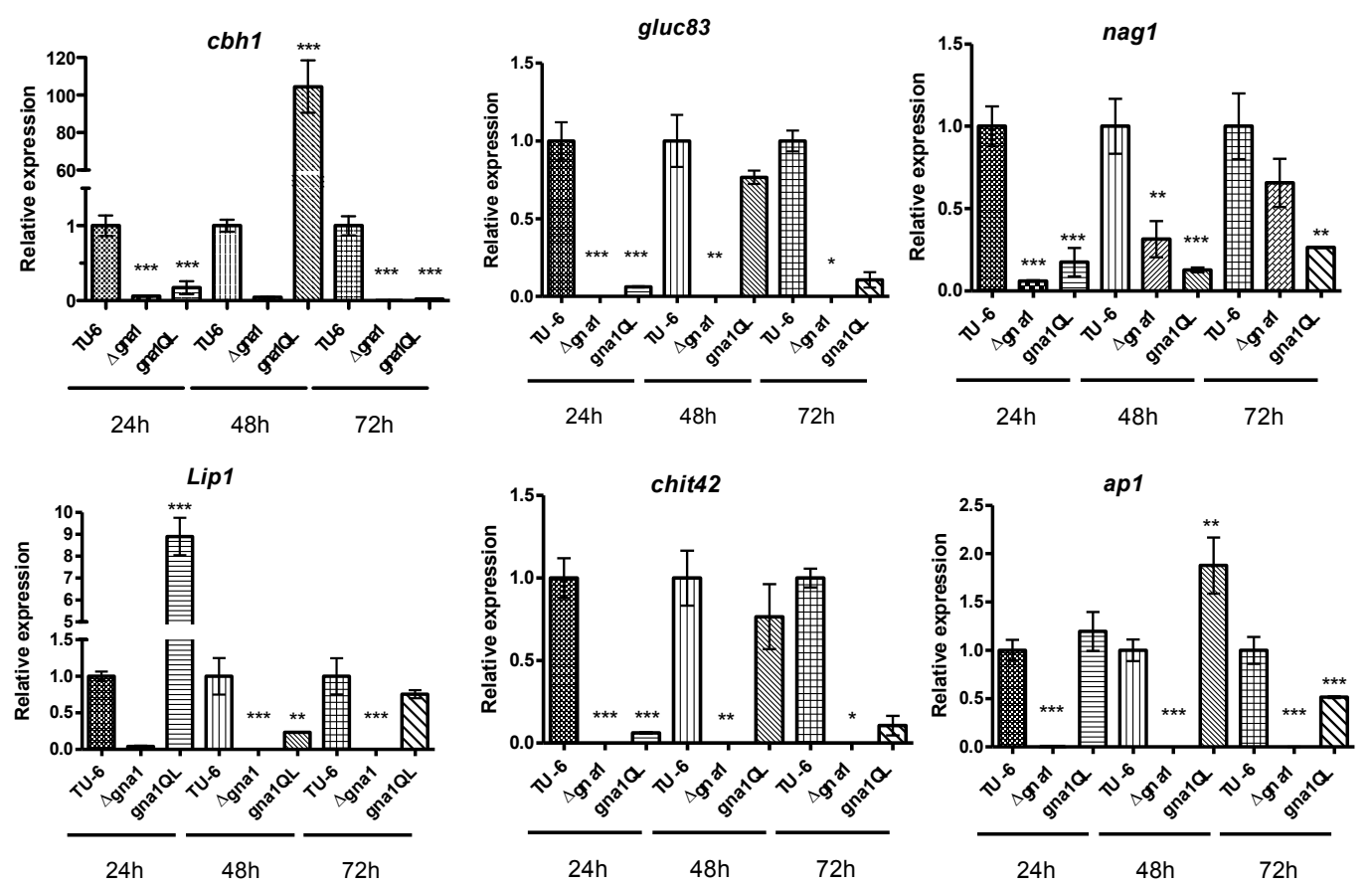

Figure 2: Differential expression analysis and quantification of transcript levels of biocontrol-related genes expressed by T. ressei(TU-6; gna1QL and $\triangle g n a 1)$ under mycoparasitic conditions against $P$. ultimum after 24,48 and 72 hours of cultivations. The data were presented as fold change using the $2^{-\Delta \Delta C} \mathrm{method}$. The results were compared by one-way ANOVA with Dunnett's posttest $\left({ }^{*} p \leq 0.05 ;{ }^{* *} p \leq 0.01 ;{ }^{* *} p \leq 0.001\right)$.
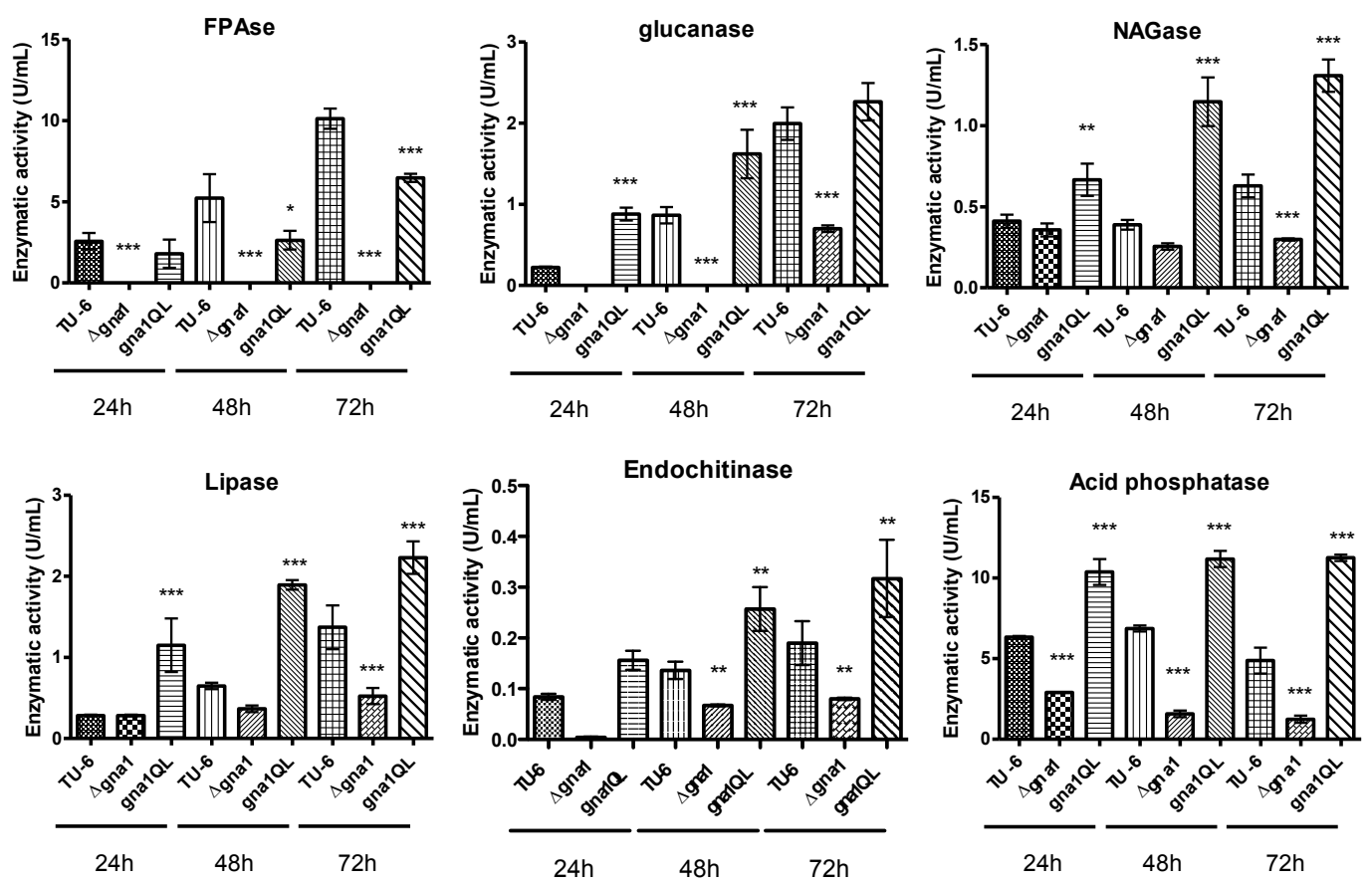

Figure 3: Enzymatic activity of cellulase (FPAse), endochitinase (chit42), NAGase (nag1), $\beta$-1,3-glucanase (gluc83), Lipase (lip1), Acid phosphatase (ap1) after 24, 48 and 72 hours of incubation of $T$. reesei (TU-6), T. reesei (gna1QL) and T. reesei ( $\Delta$ gna1) with $P$. ultimum cell wall as the carbon source. Enzyme activity was assayed by the colorimetric method as indicated in the materials and methods section. In all cases, the standard deviation values were smaller than $5 \%$ of the mean values of triplicate.

prototrophy. These strains were already studied and these G proteins are involved in cellulase formation and mediate a tolerance of osmotic and oxidative stress linked with as light as carbon source $[23,24]$.
Rocha-Ramírez and co-workers reported that a similar GNA1, Tgal of T. atroviride is involved in both coiling and conidiation (primordial factors in antagonism process). Furthermore, strains that expressed an antisense version of the gene were hypersporulating 
and coiled at a much lower frequency in the biomimetic assay [15]. Reithner and co-workers also reported that tgal gene deletion in $T$. atroviride resulted in a complete loss of overgrowth of Rhizoctonia solani, Botrytis cinerea, and Sclerotinia sclerotiorum during direct confrontation as well a decreasing in chitinase formation [17]. Our results are in accordance with that, showing that $\Delta g n a 1$ loss the capacity of overgrowth of $P$. ultimum (Figure 1). Additionally, we showed that GNA1 influences the formation of cellulase, glucanase, chitinase, lipase and acid phosphatase as well, suggesting that GNA1 are involved in mycoparasitism. Moreover, we observed that an activated mutant protein with no GTPaseactivity (gna1QL) did not affect the sporulation and coiled at a higher frequency. Opposite results were reported to $T$. virens since $\Delta$ tgaA mutants (homologue to Tgal) were not effect on growing and sporulation, compared with wild type. However, $\Delta$ tgaA mutants showed a reduced ability to colonize $S$. rolfsii sclerotia, whereas they were fully pathogenic against $R$. solani [16]. These results support the claim that different species of Trichoderma display completely different strategies to antagonize their host/prey [6] and also suggest a phytopathogenic specific response by Trichoderma, which can act in the production of lytic enzymes, secondary metabolites/antibiotics or simply competing for nutrients.

Seibel and co-workers reported that cellulase gene transcription was abolished in $\Delta g n a 1$ mutant on cellulose in light and enhanced in darkness. Our experiments were performed in day-light conditions. However, Seibel and co-workers showed that mutants expressing a constitutively activated GNA1 did not transmit the essential inducing signal for cellulase formation induced by cellulose, suggesting that the signal transduction of cellulase formation is complex and involves also GNA3 and light-carbon source dependence $[23,24]$. Although TU-6 produced higher cellulase activity, there is no guarantee that TU-6 is the best mycoparasitic antagonist against $P$. ultimum (Figure1). The antagonism of $P$. ultimum by $T$. reesei seems not to require cellulase gene expression since the negative cellulase mutant QM9978 overgrew P. ultimum on plate confrontation assays as well as protecting the plant against pathogens [4]. However, production of enzymes as cellulases and acid phosphatase by $T$. reesei are important mechanism taken together in biocontrol $[5,6]$.

Most phytopathogenic fungi have chitin and $\beta-1,3$-glucan as the main structural components. However, Pythium spp. shows approximately $82 \%$ of $\beta(1 \rightarrow 3),(1 \rightarrow 6)$-D-glucans and $18 \%$ of $\beta(1$ $\rightarrow 4$ ), together with a low chitin content (less than 1\%) [31]. These findings support the idea that $\beta$-1,3-glucanase plays an important role in mycoparasitism against $P$. ultimum and now we have evidence that the regulation of the formation of this lytic enzyme by T. reesei can be linked with G proteins and/or cAMP. However, the elucidation of the mechanism that link cAMP to chitinases and glucanases production is still unclear since do Nascimento Silva and coworkers showed that gna3QL, that rises the cAMP level, showed a similar behavior of gna1QL, instead $\triangle$ gnalmutant that shows a high intracellular cAMP content [5]. These facts could be explained since the $G$ protein pathway is involved in many cellular processes that share signaling molecules as cAMP. Thus, the response to $G$ protein actionis not a single linear sequence of cAMP pathway that was already reported to act as a positive as negative effector of endoglucanase and NAGase induction, in T. reesei and T. harzianum respectively $[22,33]$. In T. virens, on the other hand, low levels of cAMP by deletion of an adenylate cyclaseencoding gene (tacl) leads a reduction on growth and secondary metabolite production as well, impaired sporulation, and principally, and a loss in capacity to overgrow host fungi like S. rolfsii, R. solani, and Pythium sp. [34].
The role of acid phosphatase in mycoparasitism has also been suggested and seems to be involved in nutrient competition $[5,35]$ also reported a high level of activity using gna3QL for acid phosphatase, suggesting that the increase in these enzymes activity during mycoparasitism is not dependent of cAMP levels but by the activity of GNA1 or GNA3. However, more studies are needed to check this hypothesis, since the metabolism of phosphate is a complex process and involves also regulation of $\mathrm{pH}$ [36]. This study demonstrated that the production of CWDEs such as endochitinase, $\beta$-1,3-glucanase, lipase and acid phosphatase is regulated by GNA1 protein. As a consequence, mutation as gna1QL showed to improve the antagonism against $P$. ultimum in confrontation assays while the $\Delta g n a 1$ mutant was not capable to antagonize $P$. ultimum. The study contributes to understand the role of G-proteins in mycoparasitism and in biological control field by Trichoderma. Other analyses such as antifungal compound formation, competition for nutrients during in-vivo biocontrol and carbon catabolite repression in the mutants needs to be elucidated.

Taking the results together, cAMP can stimulate coiling/recognition in Trichoderma, so the cAMP pathway seems to have antagonistic roles in mycoparasitism-relevant coiling response. However, the direct action of GNA1 or GNA3 can also regulate the expression of mycoparasitism related genes independently of cAMP. In this sense, more detailed studies including signals recognizing by Trichoderma receptors and downstream targets signaling cascades will be necessary to understand the network of antagonism and mycoparasitic interaction.

\section{Acknowledgement}

This work was supported by a biotechnology research grant to C.J.U. (CNPq and FUNAPE/UFG) and FINEP / CT-AGRO / Ação Transversal - 01.07.0551.00. R.N.S is supported by The State of São Paulo Research Foundation (FAPESP) (proc. 2010/15683-8). The authors thank Dr. Sônia Nair Baó (UnB/Cel) for her support with scanning electron microscopy.

\section{References}

1. Weindling $R$ (1932) Trichoderma lignorum as a parasite of other soil fungi. Phytopathology 22: 837-845

2. Benitez T, Rincon AM, Limon MC, Codon AC (2004) Biocontrol mechanisms of Trichoderma strains. Int Microbiol 7: 249-260.

3. Schmoll M, Kubicek CP (2003) Regulation of Trichoderma cellulase formation: lessons in molecular biology from an industrial fungus. A review. Acta Microbiol Immunol Hung 50: 125-145.

4. Seidl V, Schmoll M, Scherm B, Balmas V, Seiboth B, et al. (2006) Antagonism of Pythium blight of zucchini by Hypocrea jecorina does not require cellulase gene expression but is improved by carbon catabolite derepression. FEMS Microbiol Lett 257: 145-151.

5. do Nascimento Silva R, Steindorff AS, Ulhoa CJ, Félix CR (2009) Involvement of G-alpha protein GNA3 in production of cell wall-degrading enzymes by Trichoderma reesei (Hypocrea jecorina) during mycoparasitism against Pythium ultimum. Biotechnol Lett 31: 531-536.

6. Atanasova L, Le Crom S, Gruber S, Coulpier F, Seidl-Seiboth V, et al. (2013) Comparative transcriptomics reveals different strategies of Trichoderma mycoparasitism. BMC Genomics 14: 121

7. Zeilinger S, Omann M (2007) Trichoderma biocontrol: signal transduction pathways involved in host sensing and mycoparasitism. Gene Regul Syst Bio 1: $227-234$.

8. Almeida FB, Cerqueira FM, Silva Rdo N, Ulhoa CJ, Lima AL (2007) Mycoparasitism studies of Trichoderma harzianum strains against Rhizoctonia solani: evaluation of coiling and hydrolytic enzyme production. Biotechnol Lett 29: 1189-1193.

9. De Marco JL, Felix CR (2002) Characterization of a protease produced by a Trichoderma harzianum isolate which controls cocoa plant witches' broom disease. BMC Biochem 3: 3.

10. Gajera HP, Vakharia DN (2010) Molecular and biochemical characterization of 
Citation: Monteiro VN, Steindorff AS, Almeida FBR, Lopes FAC, Ulhoa CJ, et al. (2014) Trichoderma reesei Mycoparasitism against Pythium ultimum is coordinated by G-alpha Protein GNA1 Signaling. J Microb Biochem Technol 7: 001-007. doi:10.4172/1948-5948.1000173

Trichoderma isolates inhibiting a phytopathogenic fungi Aspergillus niger Van Tieghem. Physiol Mol Plant P 74: 274-282.

11. Viterbo A, Ramot O, Chemin L, Chet I (2002) Significance of Iytic enzymes from Trichoderma spp. in the biocontrol of fungal plant pathogens. Antonie Van Leeuwenhoek 81: 549-556.

12. Monteiro VN, do Nascimento Silva R, Steindorff AS, Costa FT, Noronha EF, et al. (2010) New insights in Trichoderma harzianum antagonism of fungal plant pathogens by secreted protein analysis. Curr Microbiol 61: 298-305.

13. Woo SL, Scala F, Ruocco M, Lorito M (2006) The Molecular Biology of the Interactions Between Trichoderma spp., Phytopathogenic Fungi, and Plants. Phytopathology 96: 181-185.

14. Lévesque CA, Brouwer H, Cano L, Hamilton JP, Holt C, et al. (2010) Genome sequence of the necrotrophic plant pathogen Pythium ultimum reveals original pathogenicity mechanisms and effector repertoire. Genome Biol 11: R73.

15. Rocha-Ramirez V, Omero C, Chet I, Horwitz BA, Herrera-Estrella A (2002) Trichoderma atroviride G-protein alpha-subunit gene tga1 is involved in mycoparasitic coiling and conidiation. Eukaryot Cell 1: 594-605.

16. Mukherjee PK, Latha J, Hadar R, Horwitz BA (2004) Role of two G-protein alpha subunits, TgaA and TgaB, in the antagonism of plant pathogens by Trichoderma virens. Appl Environ Microbiol 70: 542-549.

17. Reithner B, Brunner K, Schuhmacher R, Peissl I, Seidl V, et al. (2005) The G protein alpha subunit Tga1 of Trichoderma atroviride is involved in chitinase formation and differential production of antifungal metabolites. Fungal Genet Biol 42: 749-760.

18. Zeilinger S, Reithner B, Scala V, PeissI I, Lorito M, et al. (2005) Signal transduction by Tga3, a novel $\mathrm{G}$ protein alpha subunit of Trichoderma atroviride. Appl Environ Microbiol 71: 1591-1597.

19. Reithner B, Schuhmacher R, Stoppacher N, Pucher M, Brunner K, et al. (2007) Signaling via the Trichoderma atroviride mitogen-activated protein kinase Tmk 1 differentially affects mycoparasitism and plant protection. Fungal Genet Biol 44: 1123-1133.

20. Omero C, Inbar J, Rocha-Ramirez V, Herrera-Estrella A, Chet I, Horwitz BA (1999) G protein activators and cAMP promote mycoparasitic behaviour in Trichoderma harzianum. Mycological research 103:1637-1642.

21. Schuster A, Schmoll M (2010) Biology and biotechnology of Trichoderma. App Microbiol Biotechnol 87: 787-799.

22. Silva RN, da Silva SP, Brandão RL, Ulhoa CJ (2004) Regulation of N-acetylbeta-D-glucosaminidase produced by Trichoderma harzianum: evidence that cAMP controls its expression. Res Microbiol 155: 667-671.

23. Schmoll M, Schuster A, Silva Rdo N, Kubicek CP (2009) The G-alpha protein GNA3 of Hypocrea jecorina (Anamorph Trichoderma reesei) regulates cellulase gene expression in the presence of light. Eukaryot Cell 8: 410-420.
24. Seibel C, Gremel G, do Nascimento Silva R, Schuster A Kubicek CP, et al. (2009) Light-dependent roles of the G-protein alpha subunit GNA1 of Hypocrea jecorina (anamorph Trichoderma reesei). BMC Biol 7: 58

25. Druzhinina IS, Schmoll M, Seiboth B, Kubicek CP (2006) Global carbon utilization profiles of wild-type, mutant, and transformant strains of Hypocrea jecorina. Appl Environ Microbiol 72: 2126-2133.

26. Lopes FA, Steindorff AS, Geraldine AM, Brandão RS, Monteiro VN, et al (2012) Biochemical and metabolic profiles of Trichoderma strains isolated from common bean crops in the Brazilian Cerrado, and potential antagonism against Sclerotinia sclerotiorum. Fungal Biol 116: 815-824.

27. Livak KJ, Schmittgen TD (2001) Analysis of relative gene expression data using real-time quantitative PCR and the 2(-Delta Delta $C(T)$ ) Method. Methods 25 $402-408$.

28. Ramada MH, Lopes FA, Ulhoa CJ, Silva Rdo N (2010) Optimized microplate beta-1,3-glucanase assay system for Trichoderma spp. screening. J Microbio Methods 81: 6-10.

29. Miller GL (1959) Use of Dinitrosalicylic Acid Reagent for Determination of Reducing Sugar. Analytical chemistry 31: 426-428.

30. Marcello CM, Steindorff AS, da Silva SP, Silva Rdo N, Mendes Bataus LA et al. (2010) Expression analysis of the exo-beta-1,3-glucanase from the mycoparasitic fungus Trichoderma asperellum. Microbiol Res 165: 75-81.

31. Blaschek W, Käsbauer J, Kraus J, Franz G (1992) Pythium aphanidermatum: culture, cell-wall composition, and isolation and structure of antitumour storage and solubilised cell-wall (1----3),(1----6)-beta-D-glucans. Carbohydr Res 231 293-307.

32. Parsley TB, Segers GC, Nuss DL, Dawe AL (2003) Analysis of altered G-protein subunit accumulation in Cryphonectria parasitica reveals a third Galpha homologue. Curr Genet 43: 24-33.

33. Sesták S, Farkas V (1993) Metabolic regulation of endoglucanase synthesis in Trichoderma reesei: participation of cyclic AMP and glucose-6-phosphate. Can J Microbiol 39: 342-347.

34. Mukherjee M, Mukherjee PK, Kale SP (2007) cAMP signalling is involved in growth, germination, mycoparasitism and secondary metabolism in Trichoderma virens. Microbiology 153: 1734-1742.

35. Altomare C, Norvell WA, Bjorkman T, Harman GE (1999) Solubilization of phosphates and micronutrients by the plant-growth-promoting and biocontrol fungus trichoderma harzianum rifai 1295-22 Appl Environ Microbiol 65: 29262933.

36. Nozawa SR, Ferreira-Nozawa MS, Martinez-Rossi NM, Rossi A (2003) Addendum to "The $\mathrm{pH}$-induced glycosylation of secreted phosphatases is mediated in Aspergillus nidulans by the regulatory gene pacC-dependent pathway". Fungal Genet Biol 39: 286-295. 